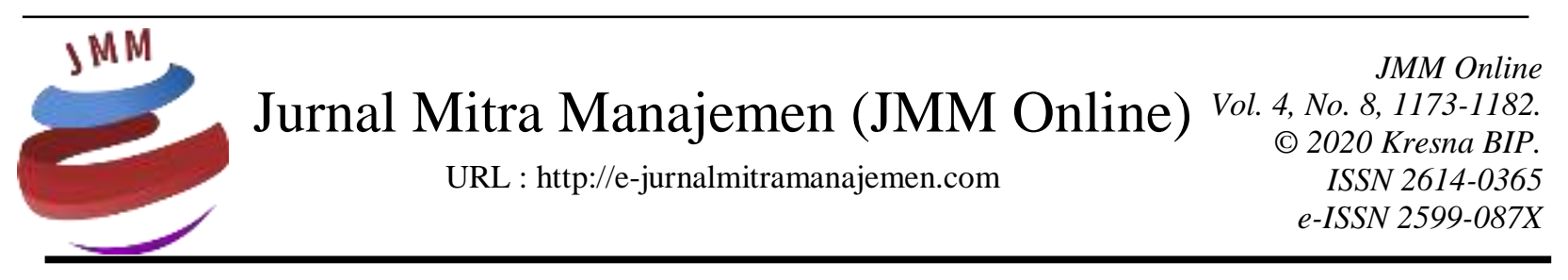

\title{
PENGARUH PENGEMBANGAN KARIR, KOMPETENSI, DAN KOMUNIKASI TERHADAP KEPUASAN KERJA KARYAWAN PADA PT SUMBER JADI KENCANA MOTOR
}

\author{
Demak Claudia Yosephine Simanjuntak ${ }^{1)}$, Andre Halim ${ }^{2)}$, Graciela ${ }^{3)}$, \\ Vina Tanri ${ }^{4)}$ \\ Universitas Prima Indonesia
}

INFORMASI ARTIKEL

Dikirim : 14 Agustus 2020

Revisi pertama : 20 Agustus 2020

Diterima : 22 Agustus 2020

Tersedia online : 27 Agustus 2020

Kata Kunci: Pengembangan Karir,

Kompetensi, Komunikasi, Kepuasan Kerja

Email : claudiayoseph8@gmail.com ${ }^{1)}$, andrelim79@gmail.com ${ }^{2)}$,

gracielachen18@gmail.com ${ }^{3)}$, vinatanri05@gmail.com ${ }^{4)}$

\section{ABSTRAK}

Penelitian ini bertujuan untuk menguji dan menganalisis pengaruh komunikasi terhadap kepuasan kerja karyawan di PT Sumber Jadi Kencana Motor Medan. Populasi adalah 132 dan sampel penelitian adalah 99 karyawan. Hasil perhitungan menunjukkan secara simultan Pengembangan Karir, Kompetensi dan Komunikasi berpengaruh positif dan signifikan terhadap Kepuasan Kerja Karyawan pada PT Sumber Jadi Kencana Motor Bidang. Secara simultan Pengembangan Karir, Kompetensi dan Komunikasi berpengaruh positif dan signifikan terhadap Kepuasan Kerja Karyawan pada PT Sumber Jadi Kencana Motor. Hasil uji koefisien determinasi diperoleh nilai Adjusted $R$ Square sebesar 0,374 hal ini berarti $37,4 \%$ dari variasi variabel terikat yaitu keputusan pembelian yang dapat dijelaskan oleh variasi variabel bebas harga, promosi penjualan dan kualitas produk sedangkan sisanya sebesar $62,6 \%$ dijelaskan oleh variabel lain yang tidak diteliti pada penelitian ini, seperti pelatihan, analisis pekerjaan, motivasi kerja dan sebagainya.

Demak Claudia Yosephine Simanjuntak ${ }^{1)}$, Andre Halim ${ }^{2)}$,

Graciela $^{3)}$, Vina Tanri ${ }^{4}$ 


\section{PENDAHULUAN}

\section{Latar Belakang}

Sumber daya manusia dalam suatu organisasi yang menjadi perencana dan pelaku aktif dalam setiap aktivitas organisasi. Kekuatan utama suatu organisasi terletak pada sumber daya manusianya. Kepuasan kerja menjadi salah satu faktor yang akan memberikan kontribusi kepada peningkatan kinerja organisasi dengan memperhatikan pengembangan karir karyawan, kompetensi karyawan dan komunikasi kerja karaywan di dalam perusahaan.

PT Sumber Jadi Kencana Motor Medan bergerak di bidang penjualan showroom sepeda motor yang bermerek Yamaha. Berdasarkan pengamatan dan wawancara terhadap beberapa karyawan PT Sumber Jadi Kencana Motor Medan bahwa terdapat banyaknya karyawan yang mengalami ketidakpuasan dalam bekerja di dalam perusahaan. PT Sumber Jadi Kencana Motor Medan dilihat bahwa bulan Januari, Februari dan April 2018 sebanyak 2 orang yang memilih resign dari perusahaan PT Sumber Jadi Kencana Motor Medan. Beberapa permasalahan karyawan mengundurkan diri adalah kompensasi yang tidak memuaskan, sistem manajemen yang tidak baik, konflik kerja, pekerjaan yang terlalu banyak, dan sebagainya.

Pengembangan karier pada perusahaan PT Sumber Jadi Kencana Motor Medan yang diadakan cukup sedikit. Di mana pengembangan karier yang terlaksana dalam perusahaan hanya memberikan pelatihan kerja, pemberian promosi jabatan dan sebagainya sehingga menyebabkan kinerja karyawan mengalami penurunan. Pengembangan karir karyawan yang dilaksanakan karyawan belum didukung sepenuhnya oleh perusahaan yang terlihat dari sedikitnya karyawan yang memperoleh pengembangan karier. Promosi jabatan bukan berdasarkan prestasi kerja karyawan tetapi dikarenakan jabatan yang sedang kosong, jadwal pelatihan seminar pada saat hari libur dan sulit beradaptasi dengan pekerjaan mencerminkan bahwa tidak mendukungnya perusahaan untuk karier karyawan.

Pada perusahaan kurangnya penempatan kerja karyawan yang sesuai dengan kompetensi kerja yang dimilikinya baik dari segi pengalaman dan pendidikan yang dimiliki oleh karyawan. Hal ini menyebabkan sebagian besar karyawan kurang memahami dengan cepat tugas-tugas mereka sehingga mengakibatkan kepuasan kerjakaryawan mengalami penurunan. Banyaknya karyawan yang mempunyai pendidikan yang tidak sesuai dengan jabatannya saat ini sehingga kurang dapat mendukung karyawan bekerja dengan cepat, tepat dan efisien. Beberapa masalah yang diakibatkan adalah kurang berpengetahuan, kurang mempunyai keahlian dalam mengajak pelanggan dan Kurang mempunyai keahlian yang sesuai sehingga sulit beradapatsi.

Permasalahan komunikasi kerja pada perusahaan ini adalah ketidakjelasan dalam berkomunikasi, kurang mendukungnya peralatan dan perlengkapan komunikasi sehingga menyebabkan tingginya tingkat kesalahan kerja karyawan di dalam perusahaan ini. Hal ini disebabkan komunikasi yang terjadi kurang akurat, kurang dapat dipahami sehingga menyebabkan terjadinya kesalahan dalam pelaksanaan tugas maupun terkadang menimbulkan konflik antara sesama karyawan. Seringnya terjadi kesalahan kerja yang disebabkan komunikasi yang kurang terjalin dengan baik dan jelas sehingga menyebabkan kurang efektif dan efisiennya karyawan dalam bekerja.

Demak Claudia Yosephine Simanjuntak ${ }^{1)}$, Andre Halim ${ }^{2)}$, Graciela $^{3)}$, Vina Tanri ${ }^{4}$ 
Hal ini disebabkan ketidakjelasan dalam berkomunikasi baik dalam penyampaian intruksi pekerjaan maupun informasi pekerjaanya di beberapa divisi dalam perusahaan sehingga menyebabkan ketidakpahaman karyawan dalam penerimaan pesan atau informasi berdampak pada kesalahan dalam pelaksanaan tugasnya.

Berdasarkan latar belakang permasalahan yang terjadi pada perusahaan, maka peneliti tertarik untuk melakukan penelitian pada perusahaan ini dengan judul "Pengaruh Pengembangan Karir, Kompetensi dan Komunikasi terhadap Kepuasan Kerja Karyawan pada PT Sumber Jadi Kencana Motor Medan”.

\section{Rumusan Masalah}

Berdasarkan latar belakang masalah yang telah dikemukakan sebelumnya, maka dapat disajikan masalah pokok yakni sebagai berikut :

1. Bagaimana pengaruh Pengembangan Karir terhadap Kepuasan Kerja Karyawan pada PT Sumber Jadi Kencana Motor Medan?

2. Bagaimana pengaruh Kompetensi terhadap Kepuasan Kerja Karyawan pada PT Sumber Jadi Kencana Motor Medan?

3. Bagaimana pengaruh Komunikasi terhadap Kepuasan Kerja Karyawan pada PT Sumber Jadi Kencana Motor Medan?

4. Bagaimana pengaruh Pengembangan Karir, Kompetensi dan Komunikasi terhadap Kepuasan Kerja Karyawan pada PT Sumber Jadi Kencana Motor Medan?

\section{Tujuan Penelitian} berikut :

Tujuan yang ingin dicapai dengan diadakannya penelitian ini adalah sebagai

1. Menguji dan menganalisa pengaruh Pengembangan Karir terhadap Kepuasan Kerja Karyawan pada PT Sumber Jadi Kencana Motor Medan.

2. Menguji dan menganalisa pengaruh Kompetensi terhadap Kepuasan Kerja Karyawan pada PT Sumber Jadi Kencana Motor Medan.

3. Menguji dan menganalisa pengaruh Komunikasi terhadap Kepuasan Kerja Karyawan pada PT Sumber Jadi Kencana Motor Medan.

4. Menguji dan menganalisa pengaruh Pengembangan Karir, Kompetensi dan Komunikasi terhadap Kepuasan Kerja Karyawan pada PT Sumber Jadi Kencana Motor Medan

\section{KAJIAN PUSTAKA}

\section{Teori Pengaruh Pengembangan Karir terhadap Kepuasan Kerja}

Menurut Darodjat (2015:320) beberapa yang penting faktor yang menentukan kepuasan kerja karyawan kepuasan kerja karyawan dalam organisasi adalah bekerja isi, bayar dan kebijakan promosi, kondisi kerja suportif.

\section{Teori Pengaruh Kompetensi terhadap Kepuasan Kerja}

Menurut Sedarmayanti (2015:127), kompetensi merupakan faktor kunci penentu bagi seseorang dalam menghasilkan kinerja yang sangat baik. Kompetensi merupakan faktor kunci penentu keberhasilan organisasi.

Demak Claudia Yosephine Simanjuntak ${ }^{1)}$, Andre Halim ${ }^{2)}$,

Graciela $^{3)}$, Vina Tanri ${ }^{4}$ 


\section{Teori Pengaruh Komunikasi terhadap Kepuasan Kerja}

Menurut Priansa (2015:293), Aspek ini mengukur kepuasan yang berhubungan dengan komunikasi yang berlangsung dalam pekerjaan.

\section{METODE PENELITIAN}

Penelitian ini dilakukan pada PT Sumber Jadi Kencana Motor Medan Jalan Platina Raya No. 1ABCD Medan. Waktu penelitian dilaksanakan pada bulan April 2019 sampai pada bulan September 2020.

\section{Populasi Penelitian}

Dalam penelitian ini berjumlah 132 karyawan PT Sumber Jadi Kencana Motor. Penelitian ini adalah sebanyak 99 karyawan PT Sumber Jadi Kencana Motor dan 30 karyawan PT Sumber Jadi Kencana Motor untuk pengujian validitas dan reliabilitas yang diambil dari populasi.

\section{Teknik Pengumpulan Data}

Dalam penelitian ini, pengumpulan data terkait permasalahan yang diteliti oleh peneliti dilakukan dengan cara:

1. Kuesioner

Kuesioner dalam penelitian dibagi kepada semua karyawan pada perusahaan.

2. Wawancara

Wawancara dilakukan kepada karyawan pada perusahaan

3. Studi dokumentasi

Studi dokumentasi yang digunakan dalam penelitian ini berupa buku-buku, jurnal-jurnal dan data perusahaan.

\section{Jenis dan Sumber Data}

Sumber data penelitian terdiri atas:

1. Sumber data primer

Data primer seperti meliputi wawancara dan kuesioner yang dibagikan kepada responden.

2. Sumber data sekunder

Data primer seperti studi dokumentasi.

\section{Uji Validitas}

Uji validitas dimaksudkan untuk mengukur valid atau tidaknya suatu kuesioner. Kuesioner dinyatakan valid bila pertanyaan pada kuesioner dapat mengungkapkan sesuatu yang akan diukur. Pengujian untuk menentukan signifikan atau tidak signifikan dengan membandungkan nilai $r_{\text {hitung }}$ dengan nilai $r_{\text {tabel }}$ untuk degree of freedom $=\mathrm{n}-\mathrm{k}$ dalam alpha 0,05 .

- Jika nilai $r_{\text {hitung }} \geq$ dari $r_{\text {tabel }}$, maka butir pertanyaan tersebut dikatakan valid. Besarnya $r_{\text {tabel yang diperoleh }}$ adalah sebesar $(0,361)$.

- Jika nilai $r_{\text {hitung }}<$ dari $r_{\text {tabel}}$, maka butir pertanyaan tersebut dikatakan tidak valid.

Demak Claudia Yosephine Simanjuntak ${ }^{1)}$, Andre Halim ${ }^{2)}$, Graciela $^{3)}$, Vina Tanri ${ }^{4}$ 


\section{Uji Reliabilitas}

Uji reliabilitas dimaksudkan untuk mengukur kuesioner yang merupakan indikator dari variabel. Butir pertanyaan dikatakan reliabel apabila jawaban seseorang terhadap pertanyaan konsisten. Dalam penelitian ini mnegunakan pengukuran sekali saja. Pada pengukuran ini keandalan butir pertanyaan dengan sekali menyebarkan kuesioner pada responden, kemudian hasil skornua diukur korelasinya antar skor jawaban pada butir pertanyaan yang sama dengan bantuan program SPSS dengan fasilitas Cronbach Alpha (a). suatu konstruk atau variabel dikatakan reliabel jika memberikan nilai cronbach alpha $>0,60$.

\section{HASIL PENELITIAN DAN PEMBAHASAN}

\section{Hasil Penelitian}

Analisis regresi berganda adalah sebagai berikut :

\section{Coefficients $^{\mathrm{a}}$}

Tabel 1. Hasil Analisis Regresi Linear Berganda

\begin{tabular}{|c|c|c|c|c|c|}
\hline \multirow[t]{2}{*}{ Model } & \multicolumn{2}{|c|}{$\begin{array}{l}\text { Unstandardized } \\
\text { Coefficients }\end{array}$} & \multirow{2}{*}{\begin{tabular}{|l} 
Standardized \\
Coefficients \\
Beta
\end{tabular}} & \multirow[b]{2}{*}{ t } & \multirow[b]{2}{*}{ Sig. } \\
\hline & $\mathrm{B}$ & Std. Error & & & \\
\hline 1 (Constant) & .368 & 2.045 & & .180 & .858 \\
\hline PengembanganKarir & .226 & .065 & .288 & 3.457 & .001 \\
\hline Kompetensi & .374 & .095 & 327 & 3.957 & .000 \\
\hline Komunikasi & .176 & .051 & .291 & 3.448 & .001 \\
\hline
\end{tabular}

a. Dependent Variable: Kepuasankerja

Sumber : Hasil Penelitian, diolah (2020)

$$
\mathrm{Y}=0,368+0,226 \mathrm{X} 1+0,374 \mathrm{X} 2+0,176 \mathrm{X} 3+\mathrm{e}
$$

Penjelasan regresi linier berganda diatas adalah :

1. Konstanta sebesar 0,368 menyatakan bahwa jika variabel bebas Pengembangan Karir, Kompetensi dan Komunikasi tidak ada atau konstan maka variabel terikat Kepuasan Kerja Karyawan pada sebesar 0,368 satuan.

2. Koefisien regresi variabel bebas Pengembangan Karir sebesar 0,226 dan bernilai positif, hal ini menyatakan bahwa apabila setiap kenaikan variabel bebas Pengembangan Karir 1 satuan akan meningkatkan variabel terikat Kepuasan Kerja Karyawan sebesar 0,226 satuan dengan anggapan variabel lainnya tetap.

3. Koefisien regresi variabel bebas Kompetensi sebesar 0,374 dan bernilai positif, hal ini menyatakan bahwa apabila setiap kenaikan variabel bebas Kompetensi 1 satuan akan meningkatkan variabel terikat Kepuasan Kerja Karyawan sebesar 0,374 satuan dengan anggapan variabel lainnya tetap.

4. Koefisien regresi variabel bebas Komunikasi sebesar 0,176 dan bernilai positif, hal ini menyatakan bahwa apabila setiap kenaikan variabel bebas Komunikasi 1 satuan akan meningkatkan variabel terikat Kepuasan Kerja Karyawan dan sebesar 0,176 satuan dengan anggapan variabel lainnya tetap.

Demak Claudia Yosephine Simanjuntak ${ }^{1)}$, Andre Halim ${ }^{2)}$, 


\section{Koefisien Determinasi Hipotesis}

Adjusted $R$ Square dinotasikan dengan $R^{2}$ merupakan nilai koefisien determinasi terkoreksi yang menyesuaikan $R^{2}$ dengan cara membagi tiap sum of square dengan derajat bebasnya masing-masing.

Tabel 2. Uji Koefisien Determinasi

Model Summary ${ }^{\mathrm{b}}$

\begin{tabular}{|l|l|l|l|l|}
\hline Model & R & R Square & $\begin{array}{l}\text { Adjusted } \\
\text { Square }\end{array}$ & $\begin{array}{l}\text { R } \\
\text { Std. Error of the } \\
\text { Estimate }\end{array}$ \\
\hline dimension0 1 & $.627^{\mathrm{a}}$ & .393 & .374 & 5.09402 \\
\hline
\end{tabular}

a. Predictors: (Constant), Komunikasi, Kompetensi, PengembanganKarir

b. Dependent Variable: Kepuasankerja

Sumber : Hasil Penelitian, diolah (2020)

Hasil uji koefisien determinasi diperoleh nilai Adjusted $R$ Square sebesar 0,374 hal ini berarti $37,4 \%$ dari variasi variabel terikat yaitu keputusan pembelian yang dapat dijelaskan oleh variasi variabel bebas harga, promosi penjualan dan kualitas produk sedangkan sisanya sebesar $62,6 \%(100 \%-37,4 \%)$ dijelaskan oleh variabel lain yang tidak diteliti pada penelitian ini, seperti pelatihan, analisis pekerjaan, motivasi kerja dan sebagainya.

\section{Pengujian Hipotesis Secara Simultan (Uji F)}

Pengujian statistik F pada dasarnya menunjukkan apakah semua variabel bebas yang dimasukkan dalam model mempunyai pengaruh secara simultan terhadap variabel dependen .

\section{Tabel 3. Uji Simultan (Uji F)}

ANOVA $^{b}$

\begin{tabular}{|l|l|l|l|l|l|l|}
\hline Model & & $\begin{array}{l}\text { Sum of } \\
\text { Squares }\end{array}$ & df & $\begin{array}{l}\text { Mean } \\
\text { Square }\end{array}$ & F & Sig. \\
\hline 1 & Regression & 1596.016 & 3 & 532.005 & 20.502 & $.000^{\mathrm{a}}$ \\
\hline & Residual & 2465.156 & 95 & 25.949 & & \\
\hline & 4061.172 & 98 & & & & \\
\hline
\end{tabular}

a. Predictors: (Constant), Komunikasi, Kompetensi, PengembanganKarir

b. Dependent Variable: Kepuasankerja

Sumber : Hasil Penelitian, diolah (2020)

Tabel 3 derajat bebas $1(\mathrm{df} 1)=\mathrm{k}-1=4-1=3$, dan derajat bebas $2(\mathrm{df} 2)=\mathrm{n}-\mathrm{k}$ $=99-4=95$, dimana $\mathrm{n}=$ jumlah sampel, $\mathrm{k}=$ jumlah variabel, maka nilai $\mathrm{F}$ tabel pada taraf kepercayaan signifikansi 0,05 adalah 2,70. Hasil pengujian diperoleh nilai $F$ hitung $(20,502)>\mathrm{F}$ tabel $(2,70)$ dan probabilitas signifikansi $0,000<0,05$, berarti bahwa Ha diterima Ho ditolak yaitu secara simultan Pengembangan Karir, Kompetensi dan Komunikasi berpengaruh positif dan signifikan terhadap Kepuasan Kerja Karyawan pada PT Sumber Jadi Kencana Motor Medan.

Demak Claudia Yosephine Simanjuntak ${ }^{1)}$, Andre Halim ${ }^{2)}$, 


\section{Pengujian Hipotesis Secara Parsial (Uji T)}

Uji t digunakan untuk mengetahui ada tidaknya hubungan atau pengaruh yang berarti (signifikan) antara variabel independen secara parsial terhadap variabel dependen.

Tabel 4. Uji Parsial (Uji t)

Coefficients $^{\mathbf{a}}$

\begin{tabular}{|c|c|c|c|c|c|}
\hline \multirow[t]{2}{*}{ Model } & \multicolumn{2}{|c|}{$\begin{array}{l}\text { Unstandardized } \\
\text { Coefficients }\end{array}$} & \multirow{2}{*}{\begin{tabular}{|l|} 
Standardized \\
Coefficients \\
Beta
\end{tabular}} & \multirow[b]{2}{*}{$t$} & \multirow[b]{2}{*}{ Sig. } \\
\hline & B & Std. Error & & & \\
\hline 1 (Constant) & .368 & 2.045 & & .180 & .858 \\
\hline PengembanganKarir & .226 & .065 & 288 & 3.457 & .001 \\
\hline Kompetensi & .374 & .095 & .327 & 3.957 & .000 \\
\hline Komunikasi & .176 & .051 & .291 & 3.448 & .001 \\
\hline
\end{tabular}

a. Dependent Variable: Kepuasankerja

Sumber : Hasil Penelitian, diolah (2020)

Pengujian hipotesis secara parsial adalah :

1. Hasil perhitungan pengujian hipotesis secara parsial diperoleh nilai thitung $>$ tabel atau 3,457 > 1,985 dan signifikan yang diperoleh $0,001<0,05$, berarti bahwa Ha diterima Ho ditolak yaitu secara parsial Pengembangan Karir berpengaruh positif dan signifikan terhadap Kepuasan Kerja Karyawan pada PT Sumber Jadi Kencana Motor Medan

2. Hasil perhitungan pengujian hipotesis secara parsial diperoleh nilai thitung $>$ tabel atau 3,6957 > 1,985 dan signifikan yang diperoleh 0,000 $<0,05$, berarti bahwa $\mathrm{Ha}$ diterima Ho ditolak yaitu secara parsial Kompetensi berpengaruh positif dan signifikan terhadap Kepuasan Kerja Karyawan pada PT Sumber Jadi Kencana Motor Medan.

3. Hasil perhitungan pengujian hipotesis secara parsial diperoleh nilai thitung $>$ tabel atau 3,448 $>1,985$ dan signifikan yang diperoleh $0,001<0,05$, berarti bahwa $\mathrm{Ha}$ diterima Ho ditolak yaitu secara parsial Komunikasi berpengaruh positif dan signifikan terhadap Kepuasan Kerja Karyawan pada PT Sumber Jadi Kencana Motor Medan.

\section{Pembahasan}

Pengaruh Pengembangan Karir terhadap Kepuasan Kerja Karyawan pada PT Sumber Jadi Kencana Motor Medan

Hasil perhitungan pengujian hipotesis secara parsial diperoleh nilai thitung $>$ ttabel atau 3,457 > 1,985 dan signifikan yang diperoleh $0,001<0,05$, berarti bahwa Ha diterima Ho ditolak yaitu secara parsial Pengembangan Karir berpengaruh positif dan signifikan terhadap Kepuasan Kerja Karyawan pada PT Sumber Jadi Kencana Motor Medan.

Hasil ini sejalan dengan penelitian yang dilakukan oleh Sanuddin (2013) bahwa Pengembangan Karir berpengaruh positif dan signifikan terhadap Kepuasan Kerja Karyawan.

Demak Claudia Yosephine Simanjuntak ${ }^{1)}$, Andre Halim ${ }^{2)}$, Graciela ${ }^{3)}$, Vina Tanri ${ }^{4)}$ 
Hasil ini sejalan dengan teori menurut Darodjat (2015:320) beberapa yang penting faktor yang menentukan kepuasan kerja karyawan kepuasan kerja karyawan dalam organisasi adalah bekerja isi, bayar dan kebijakan promosi, kondisi kerja suportif.

Pengembangan karier pada perusahaan PT Sumber Jadi Kencana Motor Medan yang diadakan cukup sedikit. Di mana pengembangan karier yang terlaksana dalam perusahaan hanya memberikan pelatihan kerja, pemberian promosi jabatan dan sebagainya sehingga menyebabkan kinerja karyawan mengalami penurunan. Pengembangan karir karyawan yang dilaksanakan karyawan belum didukung sepenuhnya oleh perusahaan yang terlihat dari sedikitnya karyawan yang memperoleh pengembangan karier. Promosi jabatan bukan berdasarkan prestasi kerja karyawan tetapi dikarenakan jabatan yang sedang kosong, jadwal pelatihan seminar pada saat hari libur dan sulit beradaptasi dengan pekerjaan mencerminkan bahwa tidak mendukungnya perusahaan untuk karier karyawan.

\section{Pengaruh Kompetensi terhadap Kepuasan Kerja Karyawan pada PT Sumber Jadi Kencana Motor Medan}

Hasil perhitungan pengujian hipotesis secara parsial diperoleh nilai thitung > ttabel atau 3,6957 > 1,985 dan signifikan yang diperoleh 0,000 $<0,05$, berarti bahwa $\mathrm{H}_{2}$ diterima yaitu secara parsial Kompetensi berpengaruh positif dan signifikan terhadap Kepuasan Kerja Karyawan pada PT Sumber Jadi Kencana Motor Medan.

Hasil ini sejalan dengan penelitian yang dilakukan oleh Willianto (2016) bahwa Kompetensi berpengaruh positif dan signifikan terhadap Kepuasan Kerja Karyawan.

Hasil ini sejalan dengan teori menurut Priansa (2016:252), Kompetensi pegawai yang tinggi akan sangat berpengaruh terhadap kinerja organisasi secara keseluruhan dan berdampak pada kepuasan kerjanya

Pada perusahaan kurangnya penempatan kerja karyawan yang sesuai dengan kompetensi kerja yang dimilikinya baik dari segi pengalaman dan pendidikan yang dimiliki oleh karyawan. Hal ini menyebabkan sebagian besar karyawan kurang memahami dengan cepat tugas-tugas mereka sehingga mengakibatkan kepuasan kerjakaryawan mengalami penurunan. Banyaknya karyawan yang mempunyai pendidikan yang tidak sesuai dengan jabatannya saat ini sehingga kurang dapat mendukung karyawan bekerja dengan cepat, tepat dan efisien. Beberapa masalah yang diakibatkan adalah kurang berpengetahuan, kurang mempunyai keahlian dalam mengajak pelanggan dan Kurang mempunyai keahlian yang sesuai sehingga sulit beradapatsi.

\section{Pengaruh Komunikasi terhadap Kepuasan Kerja Karyawan pada PT Sumber Jadi Kencana Motor Medan}

Hasil perhitungan pengujian hipotesis secara parsial diperoleh nilai thitung > ttabel atau 3,448 > 1,985 dan signifikan yang diperoleh 0,001 <0,05, berarti bahwa Ha diterima Ho ditolak yaitu secara parsial Komunikasi berpengaruh positif dan signifikan terhadap Kepuasan Kerja Karyawan pada PT Sumber Jadi Kencana Motor Medan.

Hasil ini sejalan dengan penelitian yang dilakukan oleh Iwan (2014) bahwa Komunikasi berpengaruh positif dan signifikan terhadap Kepuasan Kerja Karyawan.

Demak Claudia Yosephine Simanjuntak ${ }^{1)}$, Andre Halim ${ }^{2)}$, Graciela $^{3)}$, Vina Tanri ${ }^{4}$ 
Hasil ini sejalan dengan teori menurut Robbin dan Coulter (2013:17), Komunikasi organisasi yang semakin baik akan mengurangi stress akibat ambiguitas pekerjaan. Demikian pula, program perencanaan kinerja dan kepuasan.

Permasalahan komunikasi kerja pada perusahaan ini adalah ketidakjelasan dalam berkomunikasi, kurang mendukungnya peralatan dan perlengkapan komunikasi sehingga menyebabkan tingginya tingkat kesalahan kerja karyawan di dalam perusahaan ini. Hal ini disebabkan komunikasi yang terjadi kurang akurat, kurang dapat dipahami sehingga menyebabkan terjadinya kesalahan dalam pelaksanaan tugas maupun terkadang menimbulkan konflik antara sesama karyawan. Seringnya terjadi kesalahan kerja yang disebabkan komunikasi yang kurang terjalin dengan baik dan jelas sehingga menyebabkan kurang efektif dan efisiennya karyawan dalam bekerja. Hal ini disebabkan ketidakjelasan dalam berkomunikasi baik dalam penyampaian intruksi pekerjaan maupun informasi pekerjaanya di beberapa divisi dalam perusahaan sehingga menyebabkan ketidakpahaman karyawan dalam penerimaan pesan atau informasi berdampak pada kesalahan dalam pelaksanaan tugasnya.

\section{KESIMPULAN DAN SARAN \\ Kesimpulan}

Berdasarkan hasil dan pembahasan bahwa dapat disimpulkan penelitian yaitu :

1. Hasil perhitungan pengujian hipotesis secara parsial diperoleh nilai thitung $>$ tabel atau 3,457 > 1,985 dan signifikan yang diperoleh $0,001<0,05$, berarti secara parsial Pengembangan Karir berpengaruh positif dan signifikan terhadap Kepuasan Kerja Karyawan pada PT Sumber Jadi Kencana Motor Medan.

2. Hasil perhitungan pengujian hipotesis secara parsial diperoleh nilai thitung $>$ tabel atau 3,6957 > 1,985 dan signifikan yang diperoleh $0,000<0,05$, berarti secara parsial Kompetensi berpengaruh positif dan signifikan terhadap Kepuasan Kerja Karyawan pada PT Sumber Jadi Kencana Motor Medan.

3. Hasil perhitungan pengujian hipotesis secara parsial diperoleh nilai thitung $>$ ttabel atau 3,448 > 1,985 dan signifikan yang diperoleh 0,001 <0,05, berarti secara parsial Komunikasi berpengaruh positif dan signifikan terhadap Kepuasan Kerja Karyawan pada PT Sumber Jadi Kencana Motor Medan.

4. Hasil pengujian diperoleh nilai $F$ hitung $(20,502)>F$ tabel $(2,70)$ dan probabilitas signifikansi $0,000<0,05$, berarti bahwa secara simultan Pengembangan Karir, Kompetensi dan Komunikasi berpengaruh positif dan signifikan terhadap Kepuasan Kerja Karyawan pada PT Sumber Jadi Kencana Motor Medan.

\section{Saran}

Berdasarkan permasalahan yang di bahas sebelumnya adapun saran yang diberikan dalam rangka meningkatkan Kepuasan Kerja Karyawan pada PT Sumber Jadi Kencana Motor Medan adalah :

1. Memperbaiki sistem pengembangan karir karyawan dengan menerapkan program pengembangan karir yang sesuai untuk karyawan.

2. Meningkatkan kompetensi kerja karyawan dengan memberikan pelatihan kerja yang dibutuhkan.

Demak Claudia Yosephine Simanjuntak ${ }^{1)}$, Andre Halim ${ }^{2)}$, Graciela $^{3)}$, Vina Tanri ${ }^{4}$ 
3. Memperbaiki komunikasi kerja karyawan sehingga lebih jelas dan pengunakan bahasa Indonesia dalam rapat kerja.

\section{DAFTAR PUSTAKA}

Darodjat, Achmad Tubagus. 2015. Konsep-konsep Dasar Manajemen Personalia. Bandung : Refika Aditama.

Priansa, Juni Donni. 2016. Perencanaan dan Pengembangan Sumber Daya Manusia. Bandung : Alfabeta.

Sedarmayanti. 2015. Manajemen Sumber Daya Manusia Reformasi Birokrasi dan Manajemen Pegawai Negeri Sipil. Bandung : Refika Aditama.

Surjaweni, Wiratna, V. 2015. SPSS untuk Penelitian. Yogyakarta: Pustaka Baru Press.

Demak Claudia Yosephine Simanjuntak ${ }^{1)}$, Andre Halim ${ }^{2)}$, 